judicial process is to give this aid. ${ }^{37}$ For the courts, in their case-by-case encounters with arbitration, are necessarily concerned with particular disputes, and not with the broader problem of nurturing arbitration in those fields where it is most competent.

\title{
CARRIER'S DUTY OF NOTIFICATION ON AN ORDER-NOTIFY BILL OF LADING
}

The problem of a carrier's liability for failure to inform the shipper of goods on an order-notify bill of lading ${ }^{1}$ of a failure of the notify party to accept the goods has recently received renewed attention from the courts. The Massachusetts Supreme Court has considered the problem in Lapp Insulator Co. v. Boston $\& M . R . R .{ }^{2}$ which was a suit by a shipper on an order-notify bill of lading against the carrier for loss by fire of the goods while stored in the carrier's warehouse. The goods had arrived at their destination and the notify party had been duly informed, but it had not accepted them at the time of their destruction. The notify party had repeatedly promised the carrier that it would accept the goods and pay storage charges, if the latter would hold them. The carrier failed to notify the shipper of the goods of the non-acceptance, however, and on this basis the court held the carrier liable to the shipper for the value of the goods.

The only other case which has arisen concerning this problem since $1934^{3}$ is Tri-State Produce Co. v. Chicago, B. \& Q. R. Co., ${ }^{4}$ decided in the Federal courts in $1952 .{ }^{5}$ There a duty of notification was imposed on the carrier under similar circumstances. ${ }^{6}$ While the Lapp Insulator result is in accord with that reached

${ }^{37}$ Law review discussions treating the cases in detail have analyzed the problem of jurisdiction of court and arbitrator from other viewpoints without specific consideration of the role of equity. Judicial Innovations in the New York Arbitration Law, 21 Univ. Chi. L. Rev. 148 (1953); Judicial Control of Arbitrators' Jurisdiction in New York, 38 Cornell L.Q. 391 (1953); Arbitration: Its Snares and Delusions, 19 Brooklyn L.-Rev. 199 (1953).

${ }^{1}$ In this type of bill the shipper is both the consignor and the consignee of the goods. There is a direction to the carrier to notify a party at the destination point. Typically this party (the notify party) is the buyer of the goods, and upon presentation of the bill of lading.to the carrier is entitled to possession. The practice is for the seller to tender the bill of lading together with a sight draft through banking channels; upon acceptance of the draft the bank releases the bill of lading to the buyer, who then obtains the goods from the carrier.

2- Mass. -, 112 N.E. 2 d 359 (1953).

${ }^{3}$ In that year the Third Circuit Court of Appeals passed on the problem in Trinidad Bean \& Elevator Co. v. Pennsylvania R. Co., 72 F. 2d 371 (C.A. 3d, 1934).

104 F. Supp. 452 (N.D. Iowa, 1952), noted in 66 Harv. L. Rev. 351 (1952), and 37 Minn. L. Rev. 204 (1953).

5 Possibly the dearth of decisions during the period 1935-1952 is reflective of the general economic situation then prevailing. It will be noted that in a period of growing demand for goods it is less likely that buyers will fail to accept goods shipped to them; thus the situation requiring notice by the carrier to the shipper less frequently arises.

- There was no actual recovery in the Tri-State case even though the court found liability for the failure of the carrier to notify, since no loss was proved by the evidence. (The goods involved were frozen turkeys, and damages were alleged to have accrued from a drop in the 
in the Tri-State case, the Massachusetts court expressly states that it does not decide whether the duty of notification is absolute or dependent on the particular "circumstances." It is submitted that the particular "circumstances" of this case were such that the result represents a departure from what might have been expected from prior decisions governing the carrier's liability.

Although the few cases ${ }^{8}$ directly bearing on the problem cannot be reconciled, there are several major factors which the courts find important in varying degrees. Foremost among these seems to be the general custom of giving notice to the shipper of the non-acceptance of the notify party. ${ }^{9}$ In several cases emphasis is placed upon the custom in applying the common-law duty of care as a standard. Actually the custom has arisen, as is recognized by the court in Porter v. Pennsylvania R. Co., ${ }^{10}$ out of the desire of the carrier to assess demurrage charges against the shipper, ${ }^{11}$ and not primarily from the fear of liability resulting from non-notification. ${ }^{12}$ Nevertheless, the custom exists as a strong support for the decisions finding liability. ${ }^{13}$

market rather than from destruction of the goods, as in the Lapp case.) The basis for liability was found in the facts of the particular case, no rule of absolute liability being adopted.

7 - Mass. -, -, 112 N.E. 2d 359, 363 (1953).

8 The following cases seem to be directly in point: Missouri, K. \& T. R. Co. v. Jenkins, 35 Tex. Civ. App. 429, 80 S.W. 428 (1904) (no liability in absence of rejection by buyer; nonperishables involved); Samuel Hardin Grain Co. v. Chicago \& Alton Ry. Co., 134 Mo. App. 681, 114 S.W. 1117 (1908) (no liability where buyer took no action; perishable goods); Nashville, Chattanooga \& St. Louis Ry. v. Dreyfuss-Weil Co., $150 \mathrm{Ky} .333,150$ S.W. 321 (1912) (liability where buyer rejected; non-perishable goods); Emerson v. Chicago, B. \& Q. R. Co., 120 Minn. 84, 138 N.W. 1026 (1912) (liability where buyer rejected; perishable goods); South Deerfield Onion Storage Co. v. N.Y., N.H., \& H. R. Co., 222 Mass. 535, 111 N.E. 367 (1916) (liability for non-acceptance; perishable goods); Stoddard Lumber Co. v. Oregon-Washington R.R. \& Navigation Co., 84 Ore. 399, 165 Pac. 363, 4 A.L.R. 1275 (1917) (liability where buyer promised acceptance; non-perishable goods); Porter v. Pennsylvania R. Co., 217 App. Div. 49, 215 N.Y.S. 727 (4th Dep't, 1926) (liability where buyer took no action; perishable goods); Missouri Pacific R. Co. v. Myers, 173 Ark. 747, 293 S.W. 15 (1927) (liability where buyer took no action; perishable goods); Atlantic Coast Line R. Co. v. Ousley Co., 37 Ga. App. 215, 139 S.E. 586 (1927), 40 Ga. App. 555, 150 S.E. 564 (1929) (liability where buyer took no action; perishable goods); Trinidad Bean \& Elevator Co. v. Pennsylvania R. Co., 72 F. 2d 371 (C.A. 3d, 1934) (no liability where buyer took no action; perishable goods); Tri-State Produce Co. v. Chicago, B. \& Q. R. Co., 104 F. Supp. 452 (N.D. Iowa, 1952) (liability where buyer took no action; semi-perishables); Lapp Insulator Co. v. Boston \& M. R.R., - Mass. -, 112 N.E. $2 \mathrm{~d} 359$ (1953).

' E.g., Emerson v. Chicago, B. \& Q. R. Co., 120 Minn. 84, 138 N.W. 1026 (1912); Porter v. Pennsylvania R. Co., 217 App. Div. 49, 215 N.Y.S. 727 (4th Dep't, 1926); Tri-State Produce Co. v. Chicago, B. \& Q. R. Co., 104 F. Supp: 452 (N.D. Iowa, 1952).

10217 App. Div. 49, 215 N.Y.S. 727 (4th Dep't, 1926). 1952).

11 Tri-State Produce Co. v. Chicago, B. \& Q. R. Co., 104 F. Supp. 452, 458-59 (N.D. Iowa,

12 Notice was probably not given to the plaintiff in the principal case [Lapp Insulator Co. v. Boston \& M. R.R., - Mass. -, 112 N.E. 2d 359 (1953)] because the notify party promised to pay storage charges, thus lending support to the view that the custom arose as a foundation for assessing storage charges.

13 It should be noted that bills of lading do not have any explicit provision requiring notice to the shipper of non-acceptance. In fact, when the possibility of such a provision was con- 
Another factor supporting liability is the knowledge which the railroad must have of the nature of the transaction involved, i.e., that an order-notify bill is typically used by a shipper as a collection device ${ }^{14}$ to keep control of the goods from the buyer until the latter has accepted the seller's draft and obtained the bill of lading. The carrier, therefore, realizing that the shipper is interested in the disposal of the goods, should notify him of non-acceptance so that he can take the necessary steps to protect his interest..$^{15}$

Additional factors receiving consideration in the cases are the nature of the goods involved ${ }^{16}$ and the stability of the market at the time of their arrival..$^{17}$ Where the goods are known to be perishable or the market is recognized to be fluctuating the court may find added justification for a finding of liability.

In spite of these factors, the courts in several cases have been firm in denying liability for failure to notify the shipper of non-acceptance. ${ }^{18} \mathrm{~A}$ legal basis for these decisions is found by treating the notify party as the agent of the shipper and then applying the agency doctrine that notice to the agent is notice to the principal. The court in the Trinidad Bean case summarizes this position, pointing out that if a duty of notification were imposed, "we would have the strange contradiction ... where the consignor is itself the consignee of the goods, that the consignor should be advised that it, as consignee, had not accepted delivery." ${ }^{\prime 19}$ The court in the Tri-State case ${ }^{20}$ rejects this theory, holding it inapplicable in a situation where the carrier knows that the notify party is the buyer. This view seems more in harmony with the current practice, since as previously noted, the principal use of the order-notify bill of lading is as a collection device between buyer and seller.

A seemingly very important factor, which has received practically no atten-

sidered, it was expressly rejected, with the view stated that practical hardship might result from a notice requirement in all cases. In the Matter of Bills of Lading, 52 I.C.C. 671, 717-21 (1919).

14 See Uniform Sales Act, \$20(2).

${ }^{15}$ There is, of course, the probability that the seller will also receive notice from his bank that the draft has not been accepted. The cases seem uniform, where the question is considered at all, in holding that the carrier is not liable for loss after the shipper has received actual notice from the bank, or any other source.

It is interesting to note that no mention at all is made in the principal case of possible notice to the plaintiff from his bank, although a draft was forwarded through banking channels, and over $2 \frac{1}{2}$ months elapsed between the time of the arrival of the goods at their destination and the fire destroying them.

${ }^{16}$ Tri-State Produce Co. v. Chicago, B. \& Q. R. Co., 104 F. Supp. 452 (N.D. Iowa, 1952). ${ }^{17}$ Ibid., where the market for turkeys was allegedly fluctuating during the Christmas period.

${ }_{18}$ Trinidad Bean \& Elevator Co. v. Pennsylvania R. Co., 72 F. 2d 371 (C.A. 3d, 1934); Samuel Hardin Grain Co. v. Chicago \& Alton Ry. Co., 134 Mo. App. 681, 114 S.W. 1117 (1908); Missouri, K. \& T. R. Co. v. Jenkins, 80 S.W. 428 (Tex. Civ. App., 1904) (liability imposed if notify party rejected-new trial).

19 Trinidad Bean \& Elevator Co. v. Pennsylvania R. Co., 72 F. 2d 371, 372 (C.A. 3d, 1934).

${ }^{20} 104$ F. Supp. 452 (N.D. Iowa, 1952). 
tion from the courts in their determination of liability of the carrier, is the conduct of the notify party. In some cases he has absolutely rejected the goods; in others he has simply taken no action concerning them, and in still others, such as the principal case, he has promised the carrier that he will accept them. In all cases involving a rejection the courts have found a duty of notification to exist, ${ }^{21}$ but without placing emphasis upon such rejection. Likewise, in both cases in which the notify party has promised the carrier future acceptance, the courts have nevertheless found liability for failure to notify the shipper of the absence of an immediate acceptance. ${ }^{22}$ In view of these decisions it is surprising to find that in the remaining cases dealing with the simple non-acceptance situation-in the absence of either a rejection or an express promise to accept-the courts have differed upon the question of liability. ${ }^{23}$ If the carrier is to be held to a duty of notification even where it is assured of future acceptance, it would seem that logically it should be required to give notice where it has no such assurances from the notify party. The courts, however, have given very little consideration to the factual circumstances involved in the various cases.

On the basis of the foregoing considerations, the Lapp Insulator case ${ }^{24}$ may well be viewed as a departure from many of the earlier cases, including the recent Tri-State case. ${ }^{25}$ The court, in finding liability, states that it does not decide whether the duty to notify is absolute or dependent on the circumstances of the particular situation, ${ }^{26}$ thus purporting to follow the rule adopted in the TriState case. In spite of this language, however, it is difficult to visualize a set of facts which would give less cause for notification than those in the Lapp Insulator case. The goods involved were evidently not perishable, and there was no evidence of a fluctuating market. Moreover, the notify party had repeatedly promised the carrier that the goods would be accepted. In addition, a time lapse of over $2 \frac{1}{2}$ months occurred between the arrival of the goods and their destruction. The railroad could well have assumed that after such a long period of time the seller had exercised some care in inquiring either about the disposition of his goods or of the bill of lading, thus giving him actual notice of the situation. The decision of the court thus seems to lead to the conclusion that the liability imposed, if not "absolute," is not far short of it. ${ }^{27}$

${ }^{21}$ Nashville, Chattanooga \& St. Louis Ry. v. Dreyfuss-Weil Co., $150 \mathrm{Ky.} \mathrm{333,} \mathrm{150} \mathrm{S.W.} 321$ (1912); Emerson v. Chicago, B. \& Q. R. Co., 120 Minn. 84, 138 N.W. 1026 (1912).

? Stoddard Lumber Co. v. Oregon-Washington R.R. \& Navigation Co., 84 Ore. 399, 165 Pac. 363, 4 A.L.R. 1275 (1917); Lapp Insulator Co. v. Boston \& M. R.R., - Mass. -, 112 N.E. 2d 359 (1953).

${ }^{23}$ Compare, e.g., Porter v. Pennsylvania R. Co., 217 App. Div. 49, 215 N.Y.S. 727 (4th Dep't, 1926), with Trinidad Bean \& Elevator Co. v. Pennsylvania R. Co., 72 F. 2d 371 (C.A. 3d, 1934).

$$
\begin{aligned}
& 24 \text { - Mass. -, } 112 \text { N.E. 2d } 359 \text { (1953). } 25104 \text { F. Supp. } 452 \text { (N.D. Iowa, 1952). } \\
& 23 \text { - Mass. -, -, } 112 \text { N.E. 2d 359, } 363 \text { (1953). }
\end{aligned}
$$

${ }^{27} \mathrm{It}$ is interesting to compare the solution of the problem of notice to the consignor of nonacceptance in the ordinary situation where the consignor and consignee are different persons. In that situation there would seem to be no reason to hold the carrier to knowledge of any 
It should be noted that the seller in the instant case had an action against the buyer, had he elected to sue him. Under the Uniform Sales Act the risk of loss follows the property interest in goods in the absence of agreement to the contrary ${ }^{28}$ Thus under the ordinary shipment contract the risk of loss passes to the buyer at the time of delivery to the carrier, notwithstanding the retention of a security interest in the goods by the seller. ${ }^{29}$ On the other hand, under a destination contract the risk of loss does not pass to the buyer until "delivery" to him -pursuant to the terms of the contract. ${ }^{30}$

The courts have generally held that the form of the bill of lading does not determine the time at which property in the goods, and thus risk of loss, passes from seller to buyer. ${ }^{31}$ It follows that use of an order-notify bill under a shipment contract does not mean that the risk of loss remains with the seller upon his delivery to the carrier. ${ }^{32}$ If a shipment contract were involved in the Lapp Insulator case, the seller then could have sued the buyer for the price of the goods. ${ }^{33}$ If, on the other hand, a destination contract were involved, the buyer, by agreeing to take, has accepted the goods within the meaning of Section 48 of the Uniform Sales Act, and an action could be maintained by the seller for the price. ${ }^{34}$

The availability of an action against the buyer does not militate against allowing an action against the carrier, however, since the seller still has a security interest in the goods, ${ }^{35}$ as the carrier must know. Even though the risk of loss

shipper's interest in the goods, yet some cases have held the carrier liable nonetheless for failure to notify the consignor where the consignee fails to accept the goods. Other cases have spoken in more general terms, requiring reasonable care on the part of the carrier, while still others have found no liability in the absence of agreement. Simon v. Universal Carloading \& Distributing Co., 1 N.Y.S. 2d 249 (N.Y. Munic. Ct., 1938). In the situation where the consignee only delays acceptance, the general rule seems to require no notice to the consignor (contra to the order-notify bill cases). See Missouri, K. \& T. R. Co. v. Sealy Oil Mill \& Mfg. Co., 123 S.W. 2d 948 (Tex. Civ. App., 1939). Contra: American Merchants Union Express Co. v. Wolf, 79 IIl. 430 (1875). See generally, 4 A.I.R. 1285, and cases there cited.

In some order-notify cases, e.g., Atlantic Coast Line R. Co. v. Ousley Co., 37 Ga. App. 215, 139 S.E. 586 (1927), 40 Ga. App. 555, 150 S.E. 564 (1929), the court seems to say that "order notify party" equals "consignee." Strict application of such a rule would result in no liability of the carrier in situations such as the Lapp Insulator case where the notify party simply delays in accepting the goods, according to the position of most courts stated above.

28 Uniform Sales Act §22; Lott v. Delmar, 2 N.J. 229, 66 A. 2 d 25 (1949); Gillingham v. Phelps, 5 Wash. 2d 510, 105 P. 2d 825 (1940).

${ }^{29}$ Uniform Sales Act $\$ \$ 46(1), 22(a)$.

30 Uniform Sales Act \$19, Rule 5, §22; cf. Uniform Commercial Code \$2-509.

s1 Maffei v. Ginocchio, 299 Ill. 254, 132 N.E. 518 (1921); Alderman Bros. Co. v. Westinghouse Air Brake Co., 92 Conn. 419, 103 Atl. 267 (1918)..But cf. Chapman v. Nitrate Agencies Co., 225 Ala. 650, 144 So. 810 (1932).

${ }^{32}$ See Inland Seed Co. v. Washington-Idaho Seed Co., 160 Wash. 244, 294 Pac. 991 (1931).

33 Uniform Sales Act $\$ 63$. The buyer would then presumably be forced to a negligence-action against the carrier (now a warehouseman) if possible under the circumstances.

34 Uniform Sales Act $\$ 63$. The risk of loss has clearly shifted to the buyer under $\$ 22(\mathrm{~b})$.

as Uniform Sales Act \$20(2). 
has passed to the buyer, the latter may be insolvent-one of the contingencies which retention of the security interest was designed to cover. Allowance of an action by the shipper against the carrier should thus remain.

Perhaps a desirable rule governing the carrier's liability would be: where a carrier of goods on an order-notify bill of lading fails to notify the consignor of any non-acceptance of the goods by the notify party, the carrier will be absolutely liable for subsequent loss or damage; provided, however, that the carrier may be relieved of his duty of notification, where the seller has or should have knowledge eliminating the necessity of notification. Such "knowledge" could be actual notice received by the consignor from his bank, or directly from the notify party. A long delay prior to loss (such as occurred in the principal case), during which time the consignor should be expected to exercise reasonable care in inquiring as to the disposition of his goods, should also constitute "knowledge."

Such a rule seems justified by several considerations. In the first place, no great additional burden is placed on the carrier, since custom already required that notice be given. ${ }^{36}$ Moreover, the great difficulty involved in proving damages $^{37}$ should prevent a deluge of groundless suits. It may also be hoped that a rule of absolute liability would not only preserve the duty of care of the shipper, but would re-emphasize the responsibility of the carrier in this situation.

\section{THE LIMITS OF CONSTITUTIONAL INQUIRY ON HABEAS CORPUS IN INTERSTATE RENDITION}

The writ of habeas corpus, historically the guardian of human liberty in the Anglo-American world, ${ }^{1}$ is an important procedural device in interstate rendition $^{2}$ proceedings. The traditional conception of the function of the writ in such

${ }^{36}$ See note 11 supra. Interviews with freight agents reveal that the railroad is acutely aware of the necessity of giving notice in all cases where an order-notify bill is involved. It is only where an agent "slips up" that notice is not given, and in the case of perishables it is customarily given by phone or telegraph. 1952).

${ }^{37}$ E.g., Tri-State Produce Co. v. Chicago, B. \& Q. R. Co., 104 F. Supp. 452 (N.D. Iowa,

${ }^{I}$ See Ex parte Yerger, 8 Wall. (U.S.) 85 (1868). "The Great Writ (habeas corpus ad subiiciendum) always serves the function of precipitating a judicial inquiry into a claim of illegality in the petitioner's detention for the purpose of commanding his release, or other appropriate disposition, if he is found to be illegally detained. The underlying premise is, of course, that only law can justify detention, the specific contribution of the English struggle with royal prerogative in which the writ played an historic part." Hart \& Wechsler, The Federal Courts and the Federal System, 1238 (1953).

2 Rendition is normally defined as the surrender by one state of persons found within its jurisdiction to another state in whose territory they are alleged to have committed, or to have been convicted of, crime, so that they might be dealt with according to the penal laws of the latter state. Kopelman, Extradition and Rendition, 14 B. U. L. Rev. 591, 624 (1934). In strict correctness the word "extradition" applies only to the international process of surrendering fugitives, and "interstate rendition" to the comparable process between the states of the 